\title{
MUATAN KEARIFAN LOKAL \\ DALAM CERITA RAKYAT KEPULAUAN RIAU
}

\author{
Tessa Dwi Leoni ${ }^{1}$, Wahyu Indrayatti ${ }^{2}$ \\ ${ }^{1,2}$ Universitas Maritim Raja Ali Haji \\ Email: ${ }^{1)}$ tessadwileoni@gmail.com, ${ }^{2)}$ indrayattiwahyu@gmail.com
}

\begin{abstract}
This study aims to describe: (1) local wisdom reflected in the folklore Kepulaun Riau viewed from the view of life (philosophy); (2) the local wisdom reflected in the Kepulauan Riau folklore is seen from the attitude of social life, counsel, and iktibar; (3) local wisdom reflected in Kepulauan Riau folklore as seen from ceremonies or traditional ceremonies; (4) the local wisdom reflected in the Kepulauan Riau folklore is seen from the principles, norms and rules of rule embodied into a social system; and (5) the local wisdom reflected in Kepulauan Riau folklore is seen from the habits, everyday behavior of social intercourse. The problem is analyzed based on folklore theory. The method used in this research is descriptive method of analysis. This object is collected by observation; recording and interviews. Data analysis technique is done by content analysis technique. Based on the results of the study, folklore is still growing in Kepulauan Riau society. The folklore is so full of values. it also reflects local wisdom of local people who can show the pattern of customs and local cultural peculiarities. The findings of this study can be used as a basic backdrop for literary and cultural researchers to study the culture of Indonesia in general and Malay culture of Kepulauan Riau in particular. Furthermore, for the people of Kepulauan Riau itself, the findings is one of conservation efforts of Malay culture in Kepulauan Riau. In addition, the results of this study can be an alternative teaching materials, one of which can be arranged in Prosa Fiction textbook.
\end{abstract}

Keywards: Local wisdom, Folklore, Kepulauan Riau

\section{PENDAHULUAN}

Penelitian mengenai muatan kearifan lokal cerita rakyat Kepulaun Riau dilatarbelakangi oleh beberapa hal berikut. Pertama, bangsa Indonesia merupakan bangsa yang memiliki kebudayaan tinggi. Kedua, moral-spritual merupakan jati diri dari suku Melayu Kepulauan Riau yang bersumber pada nilai, kepercayaan, dan peninggalan sosial budaya Melayu yang dijadikan acuan dalam bertingkah laku dalam kehidupan sehari-hari di masyarakat. Ketiga, orang Melayu Kepulauan Riau dikenal dengan budaya berpantun yang kuat. Ajaran-ajaran kehidupan Melayu disampaikan melalui pantun dan bercerita. Penyampaian pesanpesan kehidupan yang disampaikan melalui pantun merupakan dialektika orang Melayu sebagai tanda bahwa orang Melayu menyampaikan sesuatu melalui 
keindahan. Keempat, mengkaji muatan kearifan lokal dalam cerita rakyat

Kepulauan Riau merupakan sebuah upaya pembacaan narasi masa lampau pada masa kini dan pembacaan narasi masa kini untuk menuju masa depan. Kelima, karya sastra merupakan produk kearifan yang mampu memberikan pencerahan bagi siapapun yang mengapresiasinya. Siapapun yang menikmati sastra secara mendalam akan mendapatkan pengalaman batin darinya. Berdasarkan kelima alasan di atas, kajian terhadap muatan kearifan lokal dalam cerita rakyat Kepulauan Riau penting dilakukan. Sebab, dengan usaha ini akan diperoleh gambaran yang lengkap tentang nilai-nilai kehidupan dalam cerita rakyat Kepulauan Riau.

Cerita rakyat dapat diartikan sebagai ekspresi budaya suatu masyarakat melalui bahasa tutur yang berhubungan langsung dengan berbagai aspek budaya dan susunan nilai sosial masyarakat tersebut. Pewarisan cerita rakyat dilakukan secara turun-temurun dari satu generasi ke generasi berikutnya secara lisan. Menurut Aisyah (2009) ada beberapa jenis cerita rakyat yang ada diwilayah nusantara. Pertama, dongeng, yaitu cerita yang sepenuhnya merupakan hasil imajinasi atau khayalan pengarang yang mana yang diceritakan seluruhnya belum pernah terjadi. Kedua, fabel adalah cerita rekaan tentang binatang dan dilakukan atau para pelakunya seperti harimau, kancil, dan lain sebagainya. Ketiga, hikayat adalah cerita, baik sejarah, maupun cerita roman fiktif, yang dibaca untuk pelipur lara, pembangkit semangat juang, atau sekedar untuk meramaikan pesta. Keempat, legenda adalah dongeng tentang suatu kejadian alam asal-usul suatu tempat, benda, atau kejadian disuatu tempat atau daerah. Mite adalah cerita yang mengadung dan berlatarbelakang sejarah atau hal yang sudah dipercayai orang banyak cerita tersebut pernah terjadi dan mengandung hal-hal gaib dan kesaktian luar biasa. Keenam, cerita penggeli hati adalah cerita yang mengandung kelucuan, omong kosong, kemustahilan, ketololan, dan kedunguan tapi mengandung kritik terhadap perilaku manusia/masyarakat.

Rudy (2010:51) mengungkapkan "kearifan lokal adalah koleksi fakta, konsep, kepercayaan, dan persepsi masyarakat ihwal dunia sekitar". Kearifan lokal itulah yang merupakan pelajaran tersembunyi yang selama ini belum banyak digali para ahli dan belum dipahami masyarakat luas. Berdasarkan definisi kearifan lokal dari berbagai pakar dan sudut pandang tersebut dapat disimpulkan bahwa kearifan lokal adalah 
pengetahuan-pengetahuan khas yang dimiliki masyarakat suatu daerah tertentu berdasarkan pengalamannya menjalani kehidupan dari masa ke masa dan telah terbukti dapat menciptakan kedamaian dan kesejahteraan serta mengatasi permasalahan lokal didaerah tersebut.

Berikutnya, menurut Rasidin dan Batubara (2009), kearifan lokal diklasifikasikan ke dalam lima bentuk, yaitu (1) kearifan yang berupa pandangan hidup (filosofi); (2) kearifan berupa sikap hidup sosial, nasihat dan iktibar yang diungkap dalam bentuk pepatah, perumpamaan, pantun syair atau cerita rakyat (foklor); (3) kearifan dalam seremoni atau upacara adat; (4) kearifan berupa prinsip, norma dan tata aturan yang terwujud menjadi sistem sosial; (5) kearifan berupa kebiasaan, perilaku seharihari dalam pergaulan sosial. Dengan demikian, kearifan lokal merupakan nilainilai suci yang dikembangkan dan diwariskan secara turun-temurun oleh suatu komunitas masyarakat.

Membahas kearifan lokal dalam cerita rakyat Kepulauan Riau tidak akan terlepas dari membicarakan budaya kelompok etnis Melayu Kepulauan Riau. Orang Melayu Kepulauan Riau memandang akal budi sebagai nyawa kehidupan. Jika hidup tanpa berbudi berarti bukan lagi orang Melayu
Kepulauan Riau. Bagi orang Melayu Kepulaaun Riau hidup berbudi sangat dijunjung tinggi, biarlah nyawa terlepas dari badan asalkan budi tidak hilang dari dalam diri.

\section{METODE PENELITIAN}

Penelitian ini menggunakan metode penelitian deskriptif kualitatif. Data penelitian ini adalah kearifan lokal dalam cerita rakyat Kepulauan Riau. Data tersebut dikumpulkan dari objek penelitian yaitu cerita rakyat kepulauan Riau. Objek penelitian ini dikumpulkan melalui pengamatan (dengan perekaman dan pencatatan) dan wawancara. Perekaman dilakukan untuk memeroleh cerita lisan secara lengkap yang dilakukan dengan menggunakan tape recorder. Di samping itu, pencatatan dilakukan berkaitan dengan data identitas informan, identitas cerita, simpulan-simpulan awal yang muncul, dan sebagainya. Sementara, wawancara digunakan untuk memeroleh informasi sebagai bahan eksplanasi terhadap data rekaman. Selanjutnya, data yang berupa rekaman ditranskripsi dan diterjemahkan ke dalam bahasa Indonesia, kemudian dianalisis dengan teknik content analysis dan metode pembacaan heuristik dan hermeneutik. Di samping itu, juga dilakukan wawancara untuk memperoleh pendapat masyarakat Kepulauan Riau 
tentang cerita rakyat yang ada di daerah tersebut. Cerita rakyat akan dikumpulkan dari informan dengan kriteria berikut: (1) berenkulturasi penuh, (2) terlibat langsung, (3) memunyai waktu yang cukup, (4) nonanalitis, (5) produktif.

\section{HASIL PENELITIAN}

Bentuk-bentuk kearifan lokal dalam cerita rakyat Kepulauan Riau dapat dilihat sebagai berikut.

\section{Bentuk kearifan lokal yang terkandung dalam cerita rakyat Kepulauan Riau dilihat dari pandangan hidup (filosofi).}

Terkait dengan masalah pandangan hidup, masyarakat Kepulauan Riau sudah dari zaman dahulunya memegang teguh keyakinan pada sebuah kepercayaan terhadap adanya kekuatan magis yang tidak dimiliki oleh manusia biasa. Adanya kekuatan lain dianggap mampu mencampuri jalan kehidupan manusia. Meskipun pada awalnya masih mempercayai keberadaan dewa-dewa, dan kepercayaan pada benda-benda yang dianggap meliki kekuatan sakti, pandangan hidup masyarakat Melayu di Kepulauan Riau kemudian mulai mengarah pada kehidupan yang bernuansakan Islam. Seluruh aktivitas masyarakatnya berlandaskan pada aturan agama Islam sehingga disebutlah adat bersendikan syarak, syarak bersendikan kitabullah. Artinya, seluruh kegiatan dan kehidupan masyarakat Melayu berpedoman pada ajaran dan aturan hukum Islam.

Salah satu hukum Islam yang paling dominan terkandung dalam cerita rakyat Kepulauan Riau adalah masalah pernikahan. Dari zaman dahulunya hingga saat ini, masyarakat Melayu selalu berupaya untuk menggelar resepsi pernikahan secara lebih ramai. Hal ini dapat dilihat dalam kutipan berikut.

Mendengar perkataan Datuk Loboy, perempuan itu jadi tersentuh hatinya. Tak disangkal, ia pun telah jatuh hati pada pandangan pertama saat awal pertemuan dengan Datuk Loboy. Ia pun menerima pinangan Datuk Loboy. Beberapa hari kemudian digelarlah acara pernikahan secara besar-besaran. Seluruh masyarakat yang bermukim di Gunung Kute diundang. Pestanya sangat meriah. Warga pun merasa sangat terhibur oleh acara hiburan dalam perhelatan yang diselenggarakan (Legenda Gunung Kute).

Selain terkandung dalam cerita rakyat Gunung Kute, cerita mengenai 
pernikahan juga ditampilkan dalam cerita rakyat Putri Pandan Berduri berikut.

Beberapa hari kemudian diadakanlah perhelatan besarbesaran untuk acara pernikahan Jenang Perkasa dengan Putri Pandan Berduri. Seluruh masyarakat Suku Laut dan orangorang Bintan diundang. Betapa bahagianya batin Lagoi melihat putrinya dan Jenang Perkasa duduk bersanding di pelaminan (Legenda Putri Pandan Berduri).

Begitu juga dalam kutipan cerita rakyat berikut.

$\begin{aligned} & \text { Setelah proses } \\ & \text { berlangsung, } \\ & \text { kemudian }\end{aligned}$
diadakanlah pesta pernikahan yang
sangat meriah. Keluarga pun
mengundang seluruh penduduk
kampung Bintan (Legenda Gunung
Bintan).

Berdasarkan kutipan dari beberapa cerita rakyat tersebut, jelas terlihat bagaimana muatan kearifan lokal masyarakat Kepulauan Riau dilihat dari segi filosofi yang dipegang teguh oleh masyarakatnya. Agama Islam merupakan pandangan hidup utama bagi masyarakatnya. Agama tersebut kemudian menjadikan kehidupan masyarakat menjadi lebih terarah dan teratur. Bayangkan saja bila hidup tanpa agama. Untuk masalah perkawinan saja mungkin akan terjadi banyak pertumpahan darah bila agama tidak dijadikan landasan kokoh dalam membina rumah tangga.

Pernikahan yang dilakukan oleh masyarakat Kepulauan Riau sedapat mungkin selalu diselenggarakan dengan mengadakan perhelatan secara besarbesaran. Seluruh sanak saudara, orangorang terdekat, dan masyarakat sekitar diundang ke acara pernikahan tersebut. Selain dapat menjalin tali silaturahmi, perhelatan tersebut juga dapat memberikan kesan kebersamaan, sehingga semua orang bisa ikut merasakan kebahagiaan yang tengah dirasakan oleh keluarga pengantin. Hal ini secara tidak langsung juga dapat menginformasikan kepada khalayak ramai bahwa kedua pengantin yang tengah bersanding di pelaminan telah halal menjalin kehidupan berumah tangga bersama, sehingga tidak menimbulkan fitnah dikemudian hari.

Begitulah upaya masyarakat Kepulauan Riau untuk melangsungkan sebuah pernikahan. Hingga saat ini, prosesi pernikahan dengan menggunakan adat Melayu yang bersendikan syarak masih terus dijaga dan dilestarikan oleh masyarakatnya. Meskipun semakin bertambah tahun, dengan keadaan 
wisatawan yang berkunjung ke daerah Tanjungpinang semakin meningkat, masyarakat tetap berupaya agar budaya Melayu tidak terkontaminasi oleh budaya asing.

Selanjutnya, pandangan hidup masyarakat Kepulauan Riau yang berlandaskan pada ajaran Islam juga dapat dilihat dalam kutipan berikut.

Dalam kesehariannya, Baitusen berangkat ke laut sebelum matahari terbit dan kembali setelah matahari terbenam (Legenda Pulau Senoa).

Kutipan tersebut sejalan dengan ajaran agama Islam, seperti yang terdapat di dalam surat Alquran Al Jumu'ah 10, telah diterangkan bahwa Allah selalu memberikan karunia yang banyak terhadap manusia, maka manusialah yang harus banyak berusaha dan selalu mengingat Allah agar karunia itu semakin bertambah dan bertambah.

Apabila telah tunaikan shalat, maka bertebaranlah kamu di muka bumi; dan carilah karunia Allah dan ingatlah Allah banyak-banyak supaya kamu beruntung (QS. Al Jumu'ah 10).

Selain kutipan di atas, padangan hidup masyarakat Kepulauan Riau yang berlandaskan pada ajaran agama Islam juga tercermin dari perilaku tokoh Baitusen dalam kutipan cerita rakyat berikut.

Awalnya, Baitusen hanya bekerja sebagai nelayan seperti penduduk di sekitar Punguran pada umumnya. Setiap harinya, ia pergi ke laut untuk menangkap ikan, kerang, dan beberapa jenis hewan laut lainnya yang bisa diperjualbelikan. Dengan begitu, keadaan perekonomian keluarga Baitusen dan istrinya akhirnya mulai membaik. Mereka pun mulai merasa senang dan nyaman tinggal di Pulau tersebut (Legenda Pulau Senoa).

Kutipan cerita rakyat tersebut melambangkan kekuatan pandangan masyarakat Melayu terhadap kekuasaan sang Ilahi. Dari cerita rakyat tersebut, terefleksi bahwa masyarakat percaya, setiap yang berusaha pasti akan memperoleh hasil sesuai dengan usaha yang telah ia lakukan. Sebagaimana yang diperankan oleh tokoh Baitusen. Dengan kegigihan dan kesungguhannya dalam berusaha, akhirnya ia dapat mengubah nasib perekonomian keluarganya dari yang serba kekurangan hingga menjadi lebih baik. 
Penokohan yang diperankan oleh Baitusen tersebut begitu sesuai dengan ajaran agama Islam. Allah telah menjanjikan suatu kebaikan jika makhluknya selalu berusaha. Hal ini sesuai dengan QS Ar-Rad ayat 11 bahwa "Sesungguhnya Allah tidak akan mengubah nasib suatu kaum kecuali kaum itu sendiri yang mengubahnya".

Berdasarkan beberapa kutipan di atas, dapat terlihat bahwa cerita masyarakat Kepulauan Riau yang telah hidup dari zaman dahulu, yang telah diwariskan secara turun temurun ke beberapa generasi tersebut telah menggambarkan betapa kuatnya ajaran Islam menjadi bagian yang melandasi pandangan hidup masyarakat di Kepulauan Riau. Sehingga, seluruh masyarakatnya selalu berupaya untuk berperilaku sesuai dengan ajaran dan perintah Allah.

\section{Bentuk kearifan lokal yang terefleksi dalam cerita rakyat Kepulauan Riau dilihat dari sikap hidup sosial, nasihat, dan iktibar.}

Nasihat dalam cerita rakyat seringkali diselipkan dengan gambaran perilaku baik yang disenangi banyak orang dan perilaku buruk yang bisa menimbulkan kebencian dari orang lain. Adapun perilaku buruk tersebut dapat dijadikan pelajaran untuk tidak bersikap demikian sehingga dapat menghindari halhal buruk yang tidak disukai orang banyak. Kearifan budaya lokal terkait sikap hidup sosial, nasihat, dan iktibar dalam kehidupan masyarakat Kepulauan Riau dapat dilihat pada kutipan berikut.

Bak putri raja, tutur bahasanya
sangat yang ramah dan sopan. Ia
anggun gemulai dan tidak
sombong, sehingga semua
masyarakat suku laut pun
mencintainya. (Legenda Putri
Pandan Berduri)

Berdasarkan kutipan tersebut jelaslah bahwa cerita ini begitu sarat akan nilai-nilai dan nasihat untuk dapat menjalani kehidupan sosial secara lebih baik.

Dalam hal ini juga tergambar bahwa masyarakat Kepulauan Riau sangat menghargai orang-orang yang mampu menjaga sikap dan tutur bahasanya. Hal ini juga dapat menjadi pembelajaran bagi anak generasinya bahwa setiap tindak kebaikan, perilaku yang baik dan sopan pasti akan disenangi orang banyak.

Selain dalam kutipan cerita rakyat di atas, nasihat dan pelajaran juga terefleksi dalam cerita rakyat Gunung Kute. Dalam cerita ini, dikisahkan hubungan tiga kakak beradik yang saling menyayangi. Suatu ketika, si kakak 
hendak berlayar. Ia telah berniat untuk merantau meninggalkan kampung halaman. Namun, kedua adiknya meminta sang kakak untuk mengajak mereka. Si kakak memberikan kesempatan kepada dua orang adiknya untuk ikut dengannya tetapi dengan sebuah persyaratan. Syarat yang diberikan juga lengkap dengan sangsi yang akan mereka terima jika melanggar perjanjian yang telah mereka sepakati. Hal ini dapat dilihat dalam kutipan berikut.

Suatu hari setelah matahari terbenam, sulung pun memberitahukan kepada adiknya yang nomor dua (tengah) bahwa ia akan pergi ke bagian barat gunung Rinai. Mendengar perkataan abangnya, adik nomor dua tersebut menawarkan diri untuk ikut menemani abangnya.

Abangnya berkata kepada adiknya itu, “jika kamu sanggup untuk berjanji, kamu diperbolehkan untuk ikut."

Hingga ditanya oleh adiknya, "apa gerangan janji tersebut wahai kakak?'

Abangnya menjawab, "dalam perjalanan nanti, kamu tidak diperbolehkan untuk berbicara dan melihat ke belakang." (Legenda Gunung Kute)
Setelah sang adik menyanggupi permintaan si Kakak, mereka pun memulai perjalananya. Namun, tak disangka, si adik lupa akan perjanjian yang telah ia sepakati dengan kakaknya sebelum memulai perjalanan. Di tengah perjalanan, ia menoleh ke belakang lantaran begitu terpesona melihat keindahan alam di sepanjang perjalanan mereka.

Setelah jauh berlayar, akhirnya sampailah mereka di Tanjung Telayak. Tanjung yang menawan dan menyimpan sejuta pesona alam nan indah. Si bungsu begitu terpana dan takjub melihat keindahan tanjung Telayak. Tak sedikut pun ia berkedip menyaksikan keindahan alam di depan matanya. Setelah melewati tanjung Telayak, tak sadar si bungsu masih menoleh ke belakang melihat Tanjung Telayak. Maka terputusalah kain cindai yang mengikat mereka dan tertinggallah si bungsu di Tanjung Telayak (Legenda Gunung Kute).

Berdasarkan kutipan tersebut, jelaslah terlihat bahwa dalam cerita rakyat Gunung Kute terefleksi nasihat-nasihat yang mampu menuntun masyarakatnya ke arah kebaikan. Apabila telah disepakati 
sebuah perjanjian, maka hendaknya kesepakatan tersebut tidak dilanggar. Setiap pelanggaran pasti akan ada sangsinya. Entah itu alam semesta yang akan menghukumnya atau bisa jadi hukuman dari orang yang diajak bersepakat sebelumnya. Setiap larangan yang disampaikan oleh masyarakat setempat, tentu ada landasannya. Para tetua yang menitipkan nasihat melalui cerita-cerita kepada anak dan cucunya tentu mengandung pesan yang sangat penting untuk kelangsungan hidup generasi penerusnya. Para orang-orang tua, istilahnya seperti telah banyak makan asam garam, tentu memiliki pengalaman yang lebih banyak ketimbang gerasi muda yang baru beberapa tahun menjalani kehidupan di dunia ini. Oleh sebab itu, nasihat-nasihat tersebut perlu dijaga dan diperhatikan agar tidak terjadi hal-hal yang tidak diinginkan. Begitulah masyarakat Kepulauan Riau menitipkan pesan dan nasihat-nasihat kepada generasi muda melalui cerita-cerita yang meraka sampaikan.

Selanjutnya, terkait dengan sikap hidup sosial, masyarakat Kepulauan Riau sangat mencintai kedamaian. Jika terjadi perselisihan paham antara dua belah pihak, maka lebih baik salah satunya mengalah sehingga tidak terjadi hal-hal yang dapat merusak tali kekerabatan. Hal ini dapat dilihat dalam kutipan berikut.

Konon di Pulau Galang, tersebutlah seorang pemimpin Megat, memiliki dua orang putra yang bernama Julela dan Jenang Perkasa. Kedua beradik kakak ini dari kecil hidup rukun dan damai. Namun, kerukunan itu kemudian sirna semenjak sang ayah memutuskan Julela untuk menjadi Batin di negerinya. Ia tiba-tiba saja berubah menjadi pemimpin yang sombong. Sering kali ia melontarkan kata-kata kasar kepada adiknya, Jenang Perkasa. Julela juga kerap memaksa adiknya berlaku sesuai dengan apa yang diinginkannya. Bila tidak, Julela terus mengancam hingga akhirnya Jenang Perkasa merasa sedih dengan perubahan yang dialami kakaknya.Akhirnya pada suatu hari, secara diam-diam Jenang Perkasa memutuskan untuk meninggalkan Pulau Galang (Legenda Putri Pandan Berduri).

Kutipan tersebut jelas merefleksikan bagaimana sikap hidup sosial masyarakat Kepulauan Riau. Kesantunan sikap hidup sosial terlihat dari tokoh adik yang berusaha menghindari 
pertengkaran dengan cara pergi meninggalkan wilayah istana. Meskipun sebagai anak raja, ia sama-sama memiliki kekuasaan dan kewenangan di atas wilayah kekuasaan ayah kandung mereka. Demikianlah gambaran kehidupan sosial masyarakat pada masa kerajaan pada masa itu. Hingga saat ini pun masyarakatnya masih menjaga budaya menghargai orang lain seperti yang tergambar di dalam cerita-cerita yang disamapaikan secara turun temurun oleh pewaris ceritanya itu.

Selain kutipan di atas, sikap kepedulian sosial dalam kehidupan masyarakat Kepulauan Riau juga dapat dilihat dalam cerita rakyat Sungai Jodoh berikut.

Mah Bongsu semakin dikenali banyak orang karena kedermawanannya. Ia senang berbagi dan suka membantu orangorang yang membutuhan. Ia mencintai anak-anak yatim dan piatu. Setiap kali kedatangan tamu yang berkunjung ke rumahnya, ia selalu menjamunya dengan ramah. Meskipun tamu yang datang berpakaian lusuh dan kumal sekalipun. Orang-orang kian banyak mengucapkan rasa terima kasih ke pada Mah Bongsu karena semenjak menjadi orang yang kaya raya, Mah Bongsu selalu memberi bantuan yang mencukupi

kehidupan mereka sehari-hari (Legenda Sungai Jodoh).

Kutipan cerita tersebut menyiratkan hubungan antar sesama manusia untuk senantiasa saling menyayangi dan saling perhatian satu sama lain. Jika ada salah seorang yang membutuhkan bantuan, hendaknya yang lain membantu sehingga terjalinlah sebuah bentuk hubungan yang harmonis dari sikap kepedulian dan saling melengkapi itu.

Selanjutnya, kearifan lokal masyarakat Kepulauan Riau yang menyangkut aspek norma sosial juga tercermin dalam kutipan cerita rakyat berikut.

Kebaikan keluarga kecil Daik membuat para tetangga senang berkunjung ke rumah mereka. Dari sekian banyak orang yang datang, ada seorang wanita yang diamdiam menyukai Daik. Wanita tersebut bernama Jakas. Setiap kali ada kesempatan, Jakas selalu berupaya menggoda Daik. Pada awalnya, Daik memang tidak tergoda dengan rayuan Jakas. Namun lama kelamaan Daik mulai tergoda dengan Jakas. Akhirnya, Daik dan Jakas pun menjalin hubungan tanpa sepengetahuan 
Bintan. Bintan hanya mengira kedekatan mereka hanya sebatas teman ataupun saudara. Hingga akhirnya, pada suatu ketika terdengar kabar oleh Bintan bahwa Daik menikahi Jakas. Seketika, Bintan pun merasa hatinya hancur berkeping-keping.

Sore itu, Bintan hendak memasak gambir. Ia tak menduga, tiba-tiba Daik datang ke rumahnya dengan emosi yang meledak-ledak.

Daik terus mengamuk, tapi tibatiba saja terdengar suara bunyi yang amat keras dari halaman rumahnya. Tak disangka, Demit yang tadinya terjatuh kini berubah menjadi batu yang membentuk bukit. Melihat hal itu, Bintan menjadi sangat marah. Ia tak dapat lagi menahan amarahnya. Seperti mendapat kekuatan mistis, ia mampu mengangkat kuali besar yang berisikan gambir panas yang tadinya ia rebus dan dituangkannya ke kepala Jakas.Tak dapat mengelak, Jakas pun menjerit kesakitan. Ia berguling-guling di tanah hingga akhirnya meninggal dan berubah menjadi batu yang kemudian menjadi bukit. Melihat hal itu, Daik menjadi sangat marah, lalu diambilnya pisau untuk membunuh Bintan yang telah mencelakai Jakas. Namun dengan kehendak yang maha kuasa, keduanya terpelanting. Bintan terdampar di tempat yang tak jauh dari tempat kejadian, sedangkan Daik terpelanting jauh melayang hingga hilang dari pandangan. Batu Bintan kemudian menjadi gunung Bintan dan Daik menjadi bukit Daik di Lingga. (Legenda Gunung Bintan)

Dalam legenda Gunung Bintan, tokoh Jakas merupakan tokoh yang telah menggoda suami Bintan, yaitu Daik, untuk menjalin hubungan terlarang tanpa sepengetahuan Bintan. Sebagai istri yang sah, Bintan wajar saja mempertanyakan pertanggungjawaban suami atas perilakunya tersebut, namun seharusnya tetap tenang dan menghormati suaminya sebagai pemimpin dalam rumah tangga. Namun yang terjadi bukan demikian. Sebagai dampak dari pelanggaran terhadap hukum dan norma sosial, si pelanggar akan mendapatkan ganjarannya sendiri. Ia akan menuai setiap tindakan yang ia perbuat. Maka cerita ini bagi masyarakat Kepulauan Riau dapat menjadi pedoman agar selalu berbuat dan berperilaku yang sesuai dengan norma sosial yang ada dan 
harus berupaya untuk tidak melanggarnya. Selain itu, kisah serupa juga terefleksi dalam cerita rakyat Batu Malu berikut.

Pada masa itu, hiduplah sepasang suami istri di sana. Awalnya kehidupan mereka baik-baik saja. Namun, seiring berjalannya waktu sang suami mulai berubah; kasih sayang terhadap istrinya yang sedang mengandung berkurang dan mulai jarang pulang. Sebab itulah sang istri mulai menaruh curiga atas sikap Suaminya. Kecurigaan sang istri awalnya tidaklah berlebihan. Sang istri sempat berpikir bahwa suaminya hanya sibuk bekerja untuk menafkahi keluarga. Namun, perubahan demi perubahan terus terjadi bahkan sang suami sering marah-marah. Oleh karena itu, sang istri merasa ada sesuatu yang dirahasiakan suaminya.

Suatu hari ketika suaminya pergi kerja, sang istri mengikutinya secara diam-diam. Tidak disangka, ternyata kepergian suaminya bukanlah untuk bekerja menafkahi keluarga melainkan untuk bertemu dengan perempuan lain di Pesisir (Legenda Batu Malu).
Dari kutipan tersebut dapat diambil pelajaran bahwa sehebat apapun seseorang menyembunyikan keburukan dan kebohongan, pasti suatu saat akan terbongkar juga. Seperti kata pepatah, 'sepandai-pandainya menyimpan bangkai, suatu saat baunya akan tercium juga'. Kebenaran akan muncul kepermukaan dengan jalan yang terkadang sama sekali tak terduga. Hal ini menjadi pembelajaran dalam kehidupan masyarakat Kepulauan Riau.

Dengan demikian, setiap orang yang melihat batu kemaluan dan dihubungkan dengan legenda Batu Malu, mereka akan berupaya untuk tidak berbuat dan berlaku seperti tokoh-tokoh yang diceritakan. Perselingkuhan yang diceritakan dalam legenda Batu Malu merupakan tindakan yang tercela yang amat dibenci oleh masyarakat Kepulauan Riau. Dari zaman dahulu hingga saat ini, masyarakat setempat masih menjaga agar daerahnya terbebas dari perilaku-perilaku menyimpang seperti itu. Meskipun daerah Kepulauan merupakan daerah wisata yang dikunjungi oleh banyak orang yang silih berganti, namun penjagaan terhadap perilaku tetap menjadi tugas seluruh masyarakatnya.

\section{Bentuk kearifan lokal yang terefleksi dalam cerita rakyat}




\section{Kepulauan Riau dilihat dari seremoni atau upacara adat.}

Terkait acara adat masyarakat Kepulauan Riau, refleksi seremoni dan upacara adat pernikahn tergambar jelas dalam cerita rakyat Gunung Kute. Dalam adat kebudayaan Melayu, acara pernikahan selalu didahului oleh proses lamaran untuk dapat saling mengenali antara kedua belah pihak keluarga yang akan dipersatukan dalam ikatan pernikahan. Hal ini dapat dilihat dari kutipan berikut.

Keesokan harinya, Datuk Loboy bersama rombongan kembali berkunjung ke rumah gadis pujaan hatinya dengan maksud hendak meminang. Gayung bersambut, gadis itu pun menerima pinangan Datuk Loboy. Beberapa hari kemudian, digelarlah acara pernikahan secara besar-besaran. Seluruh masyarakat yang bermukim di Gunung Kute diundang. Pestanya sangat meriah. Warga pun merasa sangat terhibur oleh acara hiburan dalam perhelatan yang diselenggarakan. (Legenda Gunung Kute)

Prosesi lamaran dalam kebudayaan masyarakat Melayu selalu dilakukan oleh pihak keluarga calon mempelai laki-laki terhadap keluarga calon mempelai perempuan. Kehormatan terletak pada kunjungan keluarga calon mempelai lakilaki, sebab dalam kebudayaan Melayu, paling pantang apalabila calon keluarga mempelai perempuan yang mendahului kunjungan untuk melamar calon mempelai laki-laki. Inilah yang membedakan prosesi adat pernikahan masyarakat Melayu dengan masyarakat suku lainnya, seperti contohnya masyarakat suku Minang yang mewarisi sistem keturunan matrilinial. Dalam kebudayaan Minang, pihak keluarga perempuanlah yang datang meminang pihak calon mempelai laki-laki. Perbedaan seremoni adat pertunangan dalam kebudayaan Melayu dengan suku lainnya juga terlihat dari hantaran yang dibawakan. Pada prosesi lamaran, keluarga calon mempelai lakilaki membawa hantaran berupa makanan dan keperluan yang akan dipakaikan oleh pihak calon mempelai perempuan. Jenis makanan yang dibawakan tidak ada tetapannya. Semuanya diserahkan pada kemampuan pihak mempelai laki-laki. Kemudian, pada acara lamaran, beberapa keluarga dalam kelompok masyarakat Melayu masih membudayakan pemberian cincin oleh orang tua perempuan dari pihak calon mempelai laki-laki kepada calon mempelai perempuan sebagai tanda penerimaan oleh keluarga calon mempelai 
laki-laki. Dari prosesi lamaran tersebut diharapkan timbulnya rasa sayang di antara kedua belah pihak keluarga sehingga dapat bersatu menjadi keluarga besar yang lebih rukun dan damai.

Setelah proses lamaran terlewati dan setelah mendapatkan kesepakatan dari kedua belak pihak calon mempelai, barulah kemudian ditetapkan hari pernikahan antara kedua calon mempelai. Perhelatan pun diadakan dengan mengundang banyak orang agar masyarakat setempat ikut merasakan kebahagiaan dari pihak keluarga yang mengundang dan secara tidak langsung dapat memberitahukan masyarakat luas bahwa mereka telah resmi sebagai sepasang suami istri.

Seremoni dan upacara adat masyarakat Kepulauan Riau selanjutnya dapat pula dilihat dalam kutipan berikut.

$\begin{array}{ll}\text { Beberapa } & \text { hari kemudian } \\ \text { diadakanlah } & \text { perhelatan besar- }\end{array}$
besaran untuk acara pernikahan Jenang Perkasa dengan Putri Pandan Berduri. Seluruh masyarakat Suku Laut dan orangorang Bintan diundang. Betapa bahagianya batin Lagoi melihat putrinya dan Jenang Perkasa duduk bersanding di pelaminan. Semua orang berbahagia dalam acara pernikahan tersebut. Banyak jenis makanan yang lezat dihidangkan, begitu pula tari-tarian digelar untuk menghibur pengantin dan seluruh tamu undangan (Legenda Putri Pandan Berduri).

Demikianlah kearifan lokal dilihat dari segi seremoni dan acara adat dalam kehidupan masyarakat Kepualauan Riau yang terrefleksi dalam beberapa kutipan cerita rakyat yang telah disajikan. Sejak zaman dahulu hingga saat ini, masyarakat masih melestarikan acara adat pernikahan yang begitu kental dengan adat kebudayaan Melayu. Budaya perhelatan yang diselenggarkan sedapat mungkin mengundang banyak orang untuk acara makan bersama. Semakin ramai tamu yang datang, semakin dirasakan pula keberkahan yang dirasakan oleh tuan rumah. Tuan rumah akan merasa sangat senang apabila ia melihat seluruh tamu undangannya terhibur dengan acara hajatan yang mereka buat.

\section{Bentuk kearifan lokal yang terefleksi dalam cerita rakyat} Kepulauan Riau dilihat dari prinsip, norma, dan tata aturan yang terwujud menjadi sistem sosial.

Kearifan lokal berupa prinsip, norma, dan tata aturan dalam kehidupan masyarakat Kepulauan Riau dapat dilihat dari cerita rakyat Putri Pandan Berduri. 
Cerita ini mengisahkan tentang orangorang suku laut, yakni suatu kelompok masyarakat yang memiliki kebudayaan tersendiri dalam kehidupan masyarakat di Kepulauan Riau. Setiap tahunnya, jumlah anggota suku laut semakin meningkat. Di dalam cerita, dituturkan bahwa keturunan keluarga Bain Lagoi pun semakin berkembang. Hal ini menyebabkan beberapa bagian keluarga baru harus berpisah dari keluarga inti untuk mendapatkan tempat tinggal yang lebih luas dan nyaman. Namun, meskipun telah berpindah tempat, orang-orang suku laut tetap menjaga adat dan mewariskannya kepada generasi penerus mereka. Mereka menjadikan adat sebagai pedoman dalam berperilaku dan bertindak dalam kehidupan sehari-hari. Hal ini dapat dilihat dalam kutipan berikut.

Meskipun tersebar di berbagai tempat, namun suku-suku yang mereka pimpin tetap berasal dari suku laut. Adat suku asal tetap menjadi pedoman aturan adat dalam kehidupan mereka (Legenda Putri Pandan Berduri).

Berdasarkan kutipan tersebut dapat dilihat bahwa betapapun anggota keluarga terpisah dari keluarga inti, namun tetap adat suku laut mereka jaga dan pelihara sebagai pedoman dalam menjalankan kehidupan. Begitu pula dengan prinsip dan norma-norma yang biasa berlaku dalam kehidupan masyarakat suku laut hingga sekarang masih terjaga.

Berdasarkan pengamatan dan wawancara yang telah dilakukan di lapangan, diperoleh informasi bahwa beberapa anak keturuan suku laut sudah banyak yang mengecap pendidikan, bahkan ada yang sudah sampai pada tahap perguruan tinggi. Mereka yang awalnya hidup di laut, yang dahulunya hanya bergaul dengan sesama suku laut sekarang sudah dapat berkomunikasi dengan masyarakat lainnya di luar aggota keluarga suku laut. Di luar, mereka begitu toleran dengan norma-norma yang ada dalam kehidupan masyarakat biasanya, namun di dalam keluarga sendiri, mereka juga menerapkan norma-norma dalam kebudayaan suku laut.

Bentuk kearifan lokal selanjutnya dari cerita rakyat Kepulauan Riau ialah mengenai norma dan aturan dalam penurunan tahta. Seperti layaknya sebuah kerajaan, biasanya yang berhak menggantikan posisi raja ialah anak tertua. Hal ini adalah untuk menghargai si sulung yang telah lahir terlebih dahulu dibanding adiknya, meskipun pada kenyataannya sang adik lebih memiliki sifat kepemimpinan dibanding saudaranya yang 
lebih tua. Muatan kearifan lokal tersebut dapat dilihat dalam kutipan berikut.

Konon di Pulau Galang, tersebutlah seorang pemimpin Megat, memiliki dua orang putra yang bernama Julela dan Jenang Perkasa. Kedua beradik kakak ini dari kecil hidup rukun dan damai. Namun, kerukunan itu kemudian sirna semenjak sang ayah memutuskan Julela untuk menjadi Batin di negerinya. Ia tiba-tiba saja berubah menjadi pemimpin yang sombong (Legenda Gunung Kute).

Jika pihak kerajaan tidak memiliki anak laki-laki, maka tahta kepemimpinan bisa dijatuhkan pada suami anak perempuannya. Hal ini dapat dilihat dalam kutipan berikut.

Merasa sudah mulai tua, Batin lagoi kemudian mengangkat Jenang Perkasa sebagai seorang Batin di Bintan sebagai pengganti dirinya. Jenang menerima permintaan mertuanya. Ia pun memimpin rakyat Bintan dengan ramah dan bijaksana. Ia menjalankan peraturan sesuai dengan aturan adat yang berlaku (Legenda Gunung Kute).
Beberapa kutipan cerita di atas dapat memperlihatkan bagaimana kehidupan masyarakat Kepulauan Riau pada masa dahulu. Beberapa kelompok masyarakat berada di bawah naungan kerajaan yang dipimpin oleh seorang raja dan dibantu oleh beberapa orang penasehat yang dipercaya oleh pihak kerajaan. Saat ini, sisa-sisa bangunan kerajaan masih dapat terlihat di beberapa wilayah Kepulauan Riau. Meskipun sistem pemerintahan sudah tidak berbentuk kerajaan lagi, namun kearifan lokal yang terefleksi dalam cerita rakyat masyarakat Kepulauan Riau hingga saat ini masih hidup dan berkembang dalam kehidupan masyarakatnya. Seperti halnya dalam sistem pemerintahan kerajaan, saat ini masyarakat tetap patuh pada pemimpin yang berkuasa di daerah Kepulauan Riau. Mereka bertindak sesuai dengan tata aturan yang berlaku dan selalu berupaya untuk taat hukum.

\section{Bentuk kearifan lokal yang terefleksi dalam cerita rakyat Kepulauan Riau dilihat dari kebiasaan dan perilaku sehari-hari dalam pergaulan sosial.}

Dari sekian banyak kebiasaan dan perilaku sehari-hari dalam kehidupan masyarakat di Kepulauan Riau, kebiasaan 
yang paling menonjol yang terefleksi dalam cerita rakyat tersebut ialah kebiasaan makan bersama sebagai bentuk berbagi atas berkah yang diperoleh orang seseorang maupun keluarga. Hal ini menunjukkan sebuah situasi kekompakan dan keakraban yang dapat menyatukan satu sama lain. Sejak zaman dahulunya, masyarakat Kepulauan Riau yang terkenal dengan kerjaannya sudah menjalani tradisi ini. Hal ini dapat dilihat dalam kutipan cerita rakyat berikut.

Pada suatu hari, Batin Lagoi pun mengadakan sebuah pertemuan. Ia mengundang seluruh masyarakat Suku Laut termasuk Jenang untuk menghadiri acara makan malam yang diadakan di rumahnya (Legenda Putri Pandan Berduri).

Tokoh Jenang yang diceritakan di dalam kutipan tersebut bukanlah bagian dari anggota masyarakat suku laut. Ia merupakan anak rantau yang singgah ke negeri tersebut untuk mencari kehidupan baru setelah meninggalkan kampung halamannya. Berdasarkan kutipan tersebut dapat terlihat bahwa acara makan bersama yang diselenggarakan oleh pihak kerajaan zaman dahulunya tidak pernah pilih kasih.

Seluruh masyarakat diperlakukan sama oleh pemimpinnya. Seluruh masyarakat Suku Laut diundang dan diperkenankan hadir dalam acara jamuan makan meskipun di antara anggota masyarakat tersebut berasal dari suku lain.

Demikianlah cerminan sikap masyarakat Kepulauan Riau dari zaman kerajaan hingga saat ini. Mereka senang berkumpul, senang berbagi dengan sesama, dan tidak membeda-bedakan antara anggota yang satu dengan yang lainnya. Dengan demikian, apa pun suku, ras, dan agamanya, siapa pun dapat duduk bersama di sebuah tempat perkumpulan yang biasanya banyak dikunjungi oleh masyarakat Kepulauan Riau. Tidak ada pembedaan di wilayah tersebut. Semuanya diperlakukan sama dan memiliki hak yang sama, sehingga kerukunan antar golongan yang berbeda tersebut dapat terjaga dan terpelihara.

Bentuk muatan kearifan lokal lain yang terkandung dalam cerita rakyat Kepulauan Riau adalah kebiasaan perilaku sehari-hari dalam mengupayakan mata pencaharian. Pada zaman dahulu, hingga sampai pada awal-awal masa kemerdekaan RI, masyarakat Kepulauan Riau banyak bermukim di daerah pinggiran pantai. Di beberapa lokasi, pantai dijadikan sebagai tempat bermukimnya orang-orang sampan yang saat ini lebih dikenal dengan orangorang suku laut. Daerah pinggiran pantai, sengaja dipilih oleh orang-orang sampan sebagai tempat menetap sementara, konon 
bermula dari kebiasaan mereka yang menjalani kehidupannya di lautan lepas. Mereka makan, tidur, dan melangsungkan segala rutinitas kehidupannya bahkan melahirkan di atas sampan. Daratan hanyalah sebagai tempat persinggahan sementara bagi mereka untuk mengambil air tawar sebagai bekal minuman selama berlayar.

Setelah ditetapkan oleh pemerintah bahwa warga tidak diizinkan lagi hidup di laut dan mereka diberi kawasan bermukim di sepanjang pantai Bintan barulah kemudian mereka menempati kawasan pantai sebagai tempat untuk melangsungkan kehidupan bersama anakanak dan cucu mereka. Hal ini dapat terlihat dari kutipan berikut.

Konon pada zaman dahulu, di Pulau Bintan, Kepulauan Riau, hiduplah sekelompok orang-orang sampan atau disebut juga orangorang suku laut. Mereka dipimpin oleh seorang pemimpin yang bernama Batin Lagoi. (Putri Pandan Berduri).

Selain dalam kutipan cerita di atas, refleksi kearifan lokal berupa kebiasaan dan perilaku sehari-hari masyarakat di Kepulauan Riau juga terdambar dalam cerita Pulau Senoa. Cerita ini dikisahkan tentang kehidupan suami istri yang bertempat tinggal di tepian pantai. Keadaan alam Kepulauan Riau yang lebih didominasi oleh wilayah laut daripada wilayah darat, membuat masyarakat Kepulauan Riau lebih mengutamakan laut sebagai fokus mata pencaharian mereka. Pada umumnya, masyarakat menjalani kehidupan sehari-hari di tepi pantai dan memenuhi semua kebutuhan hidupnya dari hasil laut.

Dalam cerita rakyat berikut, Baitusen dikisahkan sebagai tokoh utama yang bekerja sebagai nelayan. Ia berusaha memenuhi kebutuhan istri dan rumah tangganya dengan berburu hasil laut dan menjualnya ke pasaran. Hal ini dapat dilihat dalam kutipan berikut.

Awalnya, Baitusen hanya bekerja sebagai nelayan seperti penduduk di sekitar Punguran pada umumnya. Setiap harinya, ia pergi ke laut untuk menangkap ikan, kerang, dan beberapa jenis hewan laut lainnya yang bisa diperjualbelikan (Legenda Pulau Senoa).

Selain menjalani kehidupan seharihari di tepi pantai, bagi masyarakat yang tinggal di daerah daratan, biasanya mereka bekerja sebagi petani. Mereka berupaya mengolah alam sehingga dapat menghasilkan tanaman dan buah yang 
dapat dijadikan sebagai sumber makanan penduduk setempat. Dari sistem bercocok tanam, mereka juga mampu mengupayakan penyediaan makanan untuk hewan ternak sehingga kebutuhan akan lauk pauk pun dapat terpenuhi. Hal ini dapat dilihat dari kutipan berikut.

Sulung kemudian memulai hidup yang baru tanpa keberadaan adikadiknya. Ia pun berganti nama menjadi Datok Loboy. Setiap harinya ia bekerja keras membangun gunung tersebut agar terlihat indah dan nyaman untuk ditempati. Ia bekerja sebagai petani dengan tidak mengenal lelah sehingga hasil pertaniannya dapat meningkatkan produksi pangan yang mampu memenuhi kebutuhannya dan kebutuhan beberapa penduduk tak jauh dari kampungnya. Upayanya pun tidak sia-sia. Kini usahanya telah membuahkan hasil. Banyak warga yang kemudian tertarik untuk bermukim di sana. Mereka pun satu persatu mulai memboyong keluarganya untuk tinggal di Gunung Kute (Legenda Gunung Kute).

Dari kutipan di atas, dapat ditangkap muatan kearifan lokal masyarakat Kepulauan Riau yang sedari dulu hingga saat ini masih hidup dan berkembang dalam kehidupan masyarakat Kepulauan Riau. Masyarakat Kepulauan Riau senang berbagi, hidup bersama, dan membangun kebersamaan. Datok Loboy yang dipercayai sebagai orang pertama yang menghuni Kunung Kute begitu terkenal dengan keramahannya. Ia pun mengizinkan siapa saja untuk masuk ke daerah tersebut, bahkan untuk ikut bermukim bertahun-tahun bersama anak cucu mereka. Saat ini, di wilayah tersebut, masih dijumpai beberapa pemukiman penduduk meskipun keadaannya tidak seramai waktu dahulu sebelum para penjajah memasuki wilayak Kepulauan Riau.

\section{KESIMPULAN}

Masyarakat Kepulauan Riau begitu kaya akan tradisi lisan yang masih mereka jaga secara turun temurun. Hingga saat ini, cerita-cerita tersebut masih dapat didengar dari para tetua dan orang-orang di beberapa tempat di Kepulauan Riau. Meskipun cerita yang diperoleh oleh peneliti terdiri dari beberapa versi, namun inti cerita tetaplah sama. Tidak terdapat banyak perbedaan antara versi yang satu dengan yang lainnya. Perbedaan hanyalah terdapat pada penamaan tokoh yang tidak terlalu sama. Namun, nama-nama yang 
ditampilkan dalam cerita tetap menggambarkan nama-nama orang Melayu. Tentu setiap daerah memiliki ciri khas tersendiri untuk penamaan tokohtokoh. Dengan penggambaran nama tokoh pun dapat terdeteksi dari mana asal cerita rakyat tersebut.

Berdasarkan data-data yang telah peneliti peroleh di lapangan, diperoleh pula gambaran bahwa cerita-cerita rakyat masyarakat Kepulauan Riau begitu sarat akan nilai-nilai. Di dalamnya juga terkandung bentuk kearifan lokal yang terkandung dalam cerita rakyat Kepulauan Riau dilihat dari pandangan hidup (filosofi), kearifan lokal berupa sikap hidup sosial dan nasihat, kearifan lokal berupa seremoni atau upacara adat, kearifan lokal berupa prinsip, norma dan tata aturan yang terwujud menjadi sistem sosial, dan kearifan lokal berupa kebiasaan dan perilaku sehari-hari dalam pergaulan sosial. Kearifan lokal tersebut dapat menunjukkan pola kebiasaan dan kekhasan budaya masyarakat Kepulauan Riau.

\section{Ucapan Terima Kasih}

Ucapan terima kasih disampaikan kepada Direktorat Riset dan Pengabdian Masyarakat, Direktorat Jenderal
Penguatan Riset dan Pengembangan, Kemenristekdikti yang telah memberikan dana penelitian dosen pemula, serta semua pihak yang telah membantu terlaksananya penelitian ini.

\section{DAFTAR PUSTAKA}

Al Musanna. 2011. "Rasionalitas dan Aktualitas Kearifan Lokal Sebagai Basis Pendidikan Karakter" dalam Jurnal Pendidikan dan KebudayaanVolume 17. No. 5 Tahun 2011. Jakarta: Badan Penelitian dan Pengembangan Kementerian Pendidikan Nasional.

Aisyah, Nenden Lilis. 2009. Panduan Apresiasi Prosa-Fiksi dan Pembelajarannya. Bandung: Rumput Merah.

Moleong, Lexy J. 2002. Metode Penelitian Kualitatif. Bandung: Remaja Rosda Karya.

Rasyidin, Al., Siregar, Parluhutan., Batubara, Khuzaimah. 2009. "Penyerapan Nilai-nilai Budaya Lokal dalam kehidupan beragama di Medan: Studi tentang Budaya Lokal Di Medan" dalam Afif dan Bahri, Saeful. Harmonisasi Agama dan Budaya Di Indonesia (2). Jakarta: Balitbang Kemenag.

Sibarani, Robert. 2012. Kearifan Lokal (Hakikat, Peran, dan Metode Tradisi Lisan). Jakarta: Asosiasi Tradisi Lisan (ATL).

Rudy, Rita Inderawati. 2010. "Mengangkat Peran Sastra Lokal dengan Konsep Sastra untuk Semua bagi Pembentukan Karakter Bangsa" dalam Idiosinkrasi (Novi Anoegrajekti dll. (Ed.). Jakarta: Pusat Pengembangan Bahasa dan Budaya Universitas Negeri Jakarta dan Kepel Press. 